\title{
Sákit Pighati and Pag-asa: A Pastoral Reflection on Suffering During the COVID-19 Pandemic in the Philippines
}

\author{
Dalmacito A. Cordero Jr ${ }^{1}$ (D)
}

Accepted: 13 March 2021 / Published online: 27 March 2021

(c) The Author(s), under exclusive licence to Springer Science+Business Media, LLC, part of Springer Nature 2021

\begin{abstract}
This article explores the concept of suffering as experienced by Filipinos during the COVID-19 pandemic. It draws inspiration from their narratives about how they faced, managed, and struggled during this tragic event. Their experiences were interpreted and analyzed concerning Filipino culture and tradition using a modified form of thematic analysis. Findings revealed three contextualized themes: sákit (pain), pighati (grief), and pag-asa (hope). These themes are then discussed in the light of John Paul II's Salvifici Doloris. A meaningful pastoral reflection on the basic realities of suffering is formulated to clarify our understanding of such a crisis.
\end{abstract}

Keywords COVID-19 $\cdot$ Filipino $\cdot$ Hope $\cdot$ Redemption $\cdot$ Suffering

\section{Introduction}

Suffering is inevitable! No matter how hard we try, we cannot avoid pain and discomfort. These are part of the cycle of life. None of us can hold someone we love tightly enough ensuring that we will be together forever. These sentiments capture the kind of feeling that three participants have demonstrated, as reflected in their transcripts and presented in this article.

Dr. Romeo Gregorio "Greg” Macasaet III, one of the best anesthesiologists in the country, is a frontliner who felt the agonizing pain caused by COVID-19. In his text message to his fellow doctors before he died, he described the severe pain that he was going through. Liza Paqueo, the second participant, is the daughter of Patient 35 (PH35) who is Nida Paqueo, the confirmed first Filipino casualty caused by the virus. Liza's father was also tested positive for the disease and was confined in the hospital. She posted on Facebook her grief for her mother's

Dalmacito A. Cordero Jr

dalmacito.cordero@dlsu.edu.ph

1 Theology and Religious Education Department, De La Salle University, 2401 Taft Avenue, Manila, Philippines 
death and requested viewers to share the heartbreaking letter online. The main reason for such is the spread and concern of false information against their situation which is damaging and disrespectful for their family that adds to the agonizing pain they are experiencing. Lastly, Peter John Dario's viral post on Twitter also touched many netizens. Peter John is the son of Peter Dario who also died because of the virus in New Jersey. His post conveys deep regret for not saying even a single goodbye to his father when he was the one who brought him to the hospital. With that, he promised his father that he will live a meaningful life so that he can be proud of him.

These narratives of suffering are worthy of reflection and they lead us to ask the question, "how can we better understand the phenomenon of suffering?" Pope John Paul II's phenomenal apostolic letter, Salvifici Doloris (SD), can help us better understand the mystery of suffering. This letter in a Latin title is translated as "redemptive suffering" was issued in February 1984 and is even included in the Catechism of the Catholic Church. The Pope's reflection on suffering flows from his own experience of bereavement, pain, sickness, and trials when he survived the assassination attempt in 1981 (Dulles, 2003). As the translated meaning suggests, suffering is seen as something essential and beneficial. It is bound to happen, but if we consider it as an opportunity to share in the passion of Christ, then it can be redemptive-having the power to transform us for transcendence and leads us to hope for salvation. SD will be discussed more in the latter part of this paper.

The coronavirus disease (COVID-19) is caused by severe acute respiratory syndrome coronavirus 2 . This virus and disease were not known before the outbreak began in Wuhan, China in December 2019. The Canadian Health authorities notified the World Health Organization (WHO) first about the Wuhan outbreak as the first "presumptive" confirmed case of the deadly coronavirus in a resident who had returned from the central Chinese city of Wuhan, the epicenter of the outbreak of the viral disease (Thomas \& Nair, 2020). Coronaviruses are a large family of viruses that can cause respiratory infections starting from the common cold to more severe diseases in humans such as the middle east respiratory syndrome (MERS) and severe acute respiratory syndrome (SARS) (WHO, 2020). It was declared a pandemic by the WHO on March 11, 2020. A pandemic is declared when people do not have immunity from a new disease that spreads worldwide beyond expectations. Governments and health systems need to prepare for it once declared since it becomes more likely that community spread will eventually happen (Davey, 2020). As part of WHO's response to the outbreak, the Research and Development Blueprint which is a global strategy and preparedness plan was activated on December 31, 2019, to fast-track the availability of effective tests, vaccines, and medicines that can be used to save lives and avert large scale crisis (WHO, 2020).

This article explores and analyzes, in-depth, the text messages and social media posts of the participants about the concept of suffering using a modified form of thematic analysis. The result presents three recurrent themes that are manifested from the analyzed data. These themes are considered contextualized since these reflect 
certain aspects of Filipino values are discussed in the light of Salvifici Doloris and other basic theological doctrines to form a meaningful reflection in the end.

\section{Methods}

\section{Study Design}

This research utilizes a descriptive research design that is analyzed qualitatively. It describes systematically the facts and characteristics of a given population or area of interest. To determine the essential dimensions of suffering and provide a theological reflection, the transcripts of text messages and social media posts of the participants were analyzed using a modified thematic analysis. Thematic analysis (TA) is a method of analyzing qualitative data where the researcher closely examines the data to identify common themes-topics, ideas, and patterns of meaning that come up repeatedly (Caulfield, 2019). Braun and Clarke (2006) argued that TA should be a foundational method for qualitative analysis, as it provides core skills for conducting many other forms of qualitative analysis. It is a flexible method that can be adapted according to what the author aims for and what the research requires. In qualitative studies, the concept of trustworthiness is an important component. Lincoln and Guba (1985) presented an updated concept of trustworthiness by introducing the criteria of credibility, transferability, dependability, and confirmability to parallel the conventional quantitative assessment criteria of validity and reliability. To establish trustworthiness in the research findings, a six-phase process is presented and described each as shown in Table 1 (Nowell et al., (2017):

However, this research utilized a modified form of TA. Meaning, it still followed the initial steps but the final themes were determined concerning specific

Table 1 Phases of thematic analysis and brief description

\begin{tabular}{|c|c|}
\hline Phases of thematic analysis & Brief description \\
\hline Phase 1: Familiarizing yourself with your data & $\begin{array}{l}\text { Repeated reading of the data in an active way to search } \\
\text { for meanings and patterns and storing them in well- } \\
\text { organized archives }\end{array}$ \\
\hline Phase 2: Generating initial codes & $\begin{array}{l}\text { Identifying important sections of text and attaching } \\
\text { labels to index them as they relate to a theme or issue }\end{array}$ \\
\hline Phase 3: Searching for themes & $\begin{array}{l}\text { Sorting and collating all the potentially relevant coded } \\
\text { data extracts into themes }\end{array}$ \\
\hline Phase 4: Reviewing themes & $\begin{array}{l}\text { Reviewing the coded data extracts for each theme to } \\
\text { consider whether they appear to form a coherent } \\
\text { pattern }\end{array}$ \\
\hline Phase 5: Defining and naming themes & $\begin{array}{l}\text { Determining what aspect of the data each theme cap- } \\
\text { tures and identifying what is of interest about them } \\
\text { and why }\end{array}$ \\
\hline Phase 6: Producing the report & $\begin{array}{l}\text { Providing a concise, coherent, logical, nonrepetitive, } \\
\text { and interesting account of the data within and across } \\
\text { themes }\end{array}$ \\
\hline
\end{tabular}


Filipino cultural values since the participants were Filipino citizens and embody a typical Filipino character. Thus, these themes were considered "contextualized." Coding is the primary process for developing themes by identifying items of analytic interest in the data and tagging these with a coding label. A "good code" captures the qualitative richness of the phenomenon (Boyatzis, 1998). Encoding the information organizes the data to identify and develop themes from them. Themes on the other hand are patterns of thoughts or ideas that are regularly expressed in the text, specifically coming from the codes. They are then clustered or grouped according to their frequency and relatedness with one another (Cordero, 2018).

\section{Participants}

The participants in this study are selected according to the high level of popularity based on social media posts. It is important to note that all of them have experienced suffering as reflected in their testimonies that are caused by COVID-19. The variables in this research study consist of four demographic characteristics: gender, age, nationality, and occupation. Table 2 presents the basic demographic profile of the participants.

As mentioned in the Introduction, three sources went viral online: the text message of Dr. Romeo Gregorio "Greg" Macasaet III that was posted on Facebook, the open letter of Liza Paqueo, also on Facebook, and the post of Peter John Dario on Twitter.

\section{Data Collection Procedures}

Data collection was carried out online by checking the uploaded text messages and social media posts of the participants. After validating that these posts have been gaining popularity for quite some time, the participants were contacted by the researcher for permission to use their posts as reference materials in this study. These posts were then collated for data analysis. The obtained data were all written in English and so there was no translation needed. These were analyzed through familiarization of the texts, writing of exploratory notes, and then the determination of the contextualized themes. These themes were then used for theological/pastoral reflection by an engagement with the Catholic Tradition

Table 2 Participants' demographic details

\begin{tabular}{lllll}
\hline Participant & Gender & Age & Nationality & Occupation \\
\hline $\begin{array}{l}\text { Romeo Gregorio } \\
\text { Macasaet III }\end{array}$ & Male & 62 & Filipino & Medical doctor \\
$\begin{array}{l}\text { Liza Paqueo } \\
\text { Peter John Dario }\end{array}$ & Female & 47 & Filipino & Specialist in urban forest program \\
\hline
\end{tabular}


regarding the doctrine of suffering as expressed in selected biblical passages and Pope John Paul II's Salvifici Doloris.

\section{Ethical Considerations}

All procedures performed in studies involving human participants were under the ethical standards of the institutional and/or national research committee. There is no need to make the participants anonymous to protect their identity since all of them were asked by the researcher for permission to use the transcripts for the research. Liza and Peter even requested to share their posts to everybody for announcement and to pay tribute to their fallen parents, respectively. The text message of Dr. Macasaet, on the other hand, has circulated and posted on Facebook by his fellow doctors who offered the message as a show of support to a heroic colleague. The researcher was also granted permission by Dr. Jose Gonzalo Ditching, another medical doctor who received the message and posted it on his FB and cited by many.

\section{Results and Discussion}

Table 3 presents the synthesized results of the data analysis in a modified format. I included the selected transcripts, exploratory notes, and the contextualized themes. The selected highlighted words mean these are of greater significance.

The modified TA resulted in three contextualized themes which were manifested in the transcripts of the participants in connection to their experience of suffering. It is important to take note that each of these themes reflects typical Filipino values and beliefs. The themes of sákit (pain), pighati (grief), and pag-asa (hope) are an important part of the cultural tradition in the Philippines. This section discusses these themes about the narratives of the participants and then links them to a particular Filipino conception and understanding of the concept. It also presents a brief theological discourse using the said concepts after which a relevant reflection is formulated in the conclusion.

\section{Sákit (Pain): Suffering as Primarily an Agonizing Pain}

Dr. Greg, Liza, and Peter John poured out in their respective transcripts the intense pain that they felt-both physical and emotional. Seeing that he can die anytime soon, Dr. Greg described the oozing pain that he feels all over his body:

The turn of events is just no longer going in my favor. The feeling you get, aside from extreme pains all over, the difficulty of breathing, and as if all life is being sucked from your body! They will be putting cutdown lines and central tubes on me anytime soon! If they intubate me and place me on a ventilator, then the game is almost over! 


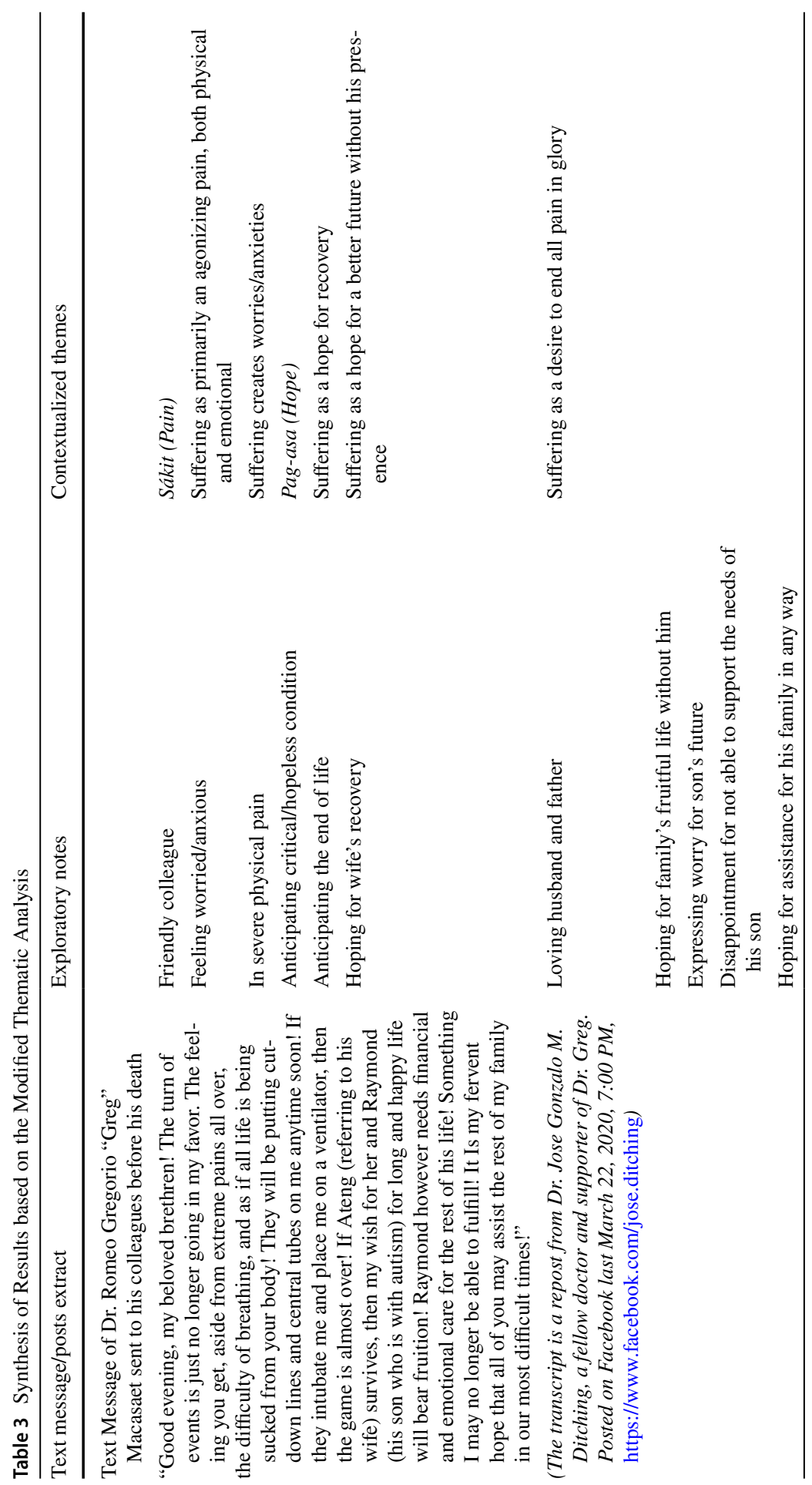




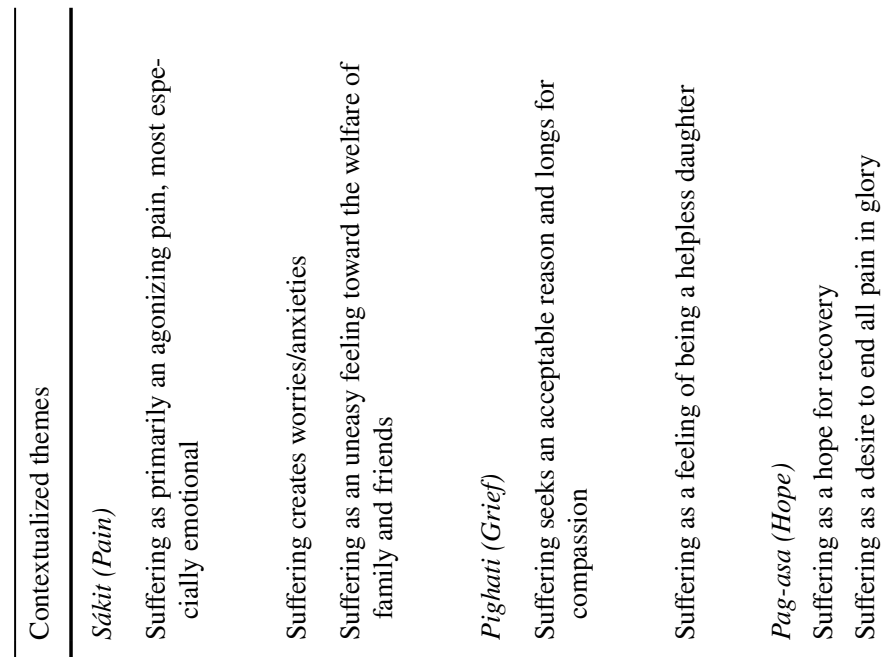

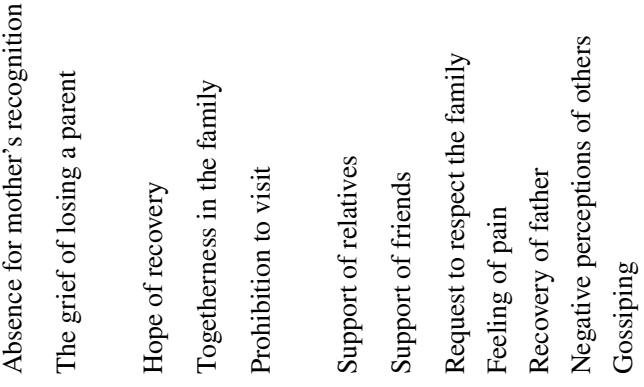

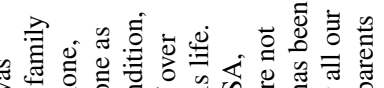

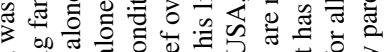

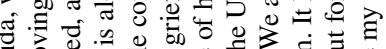

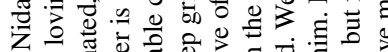

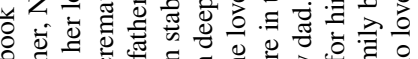

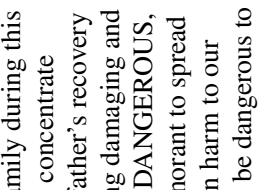

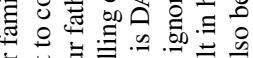

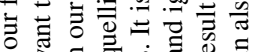

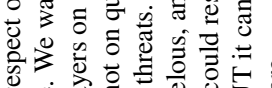

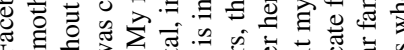

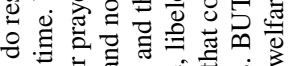

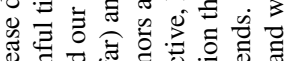

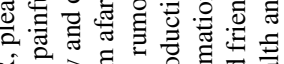

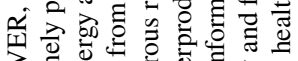

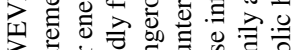

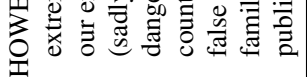




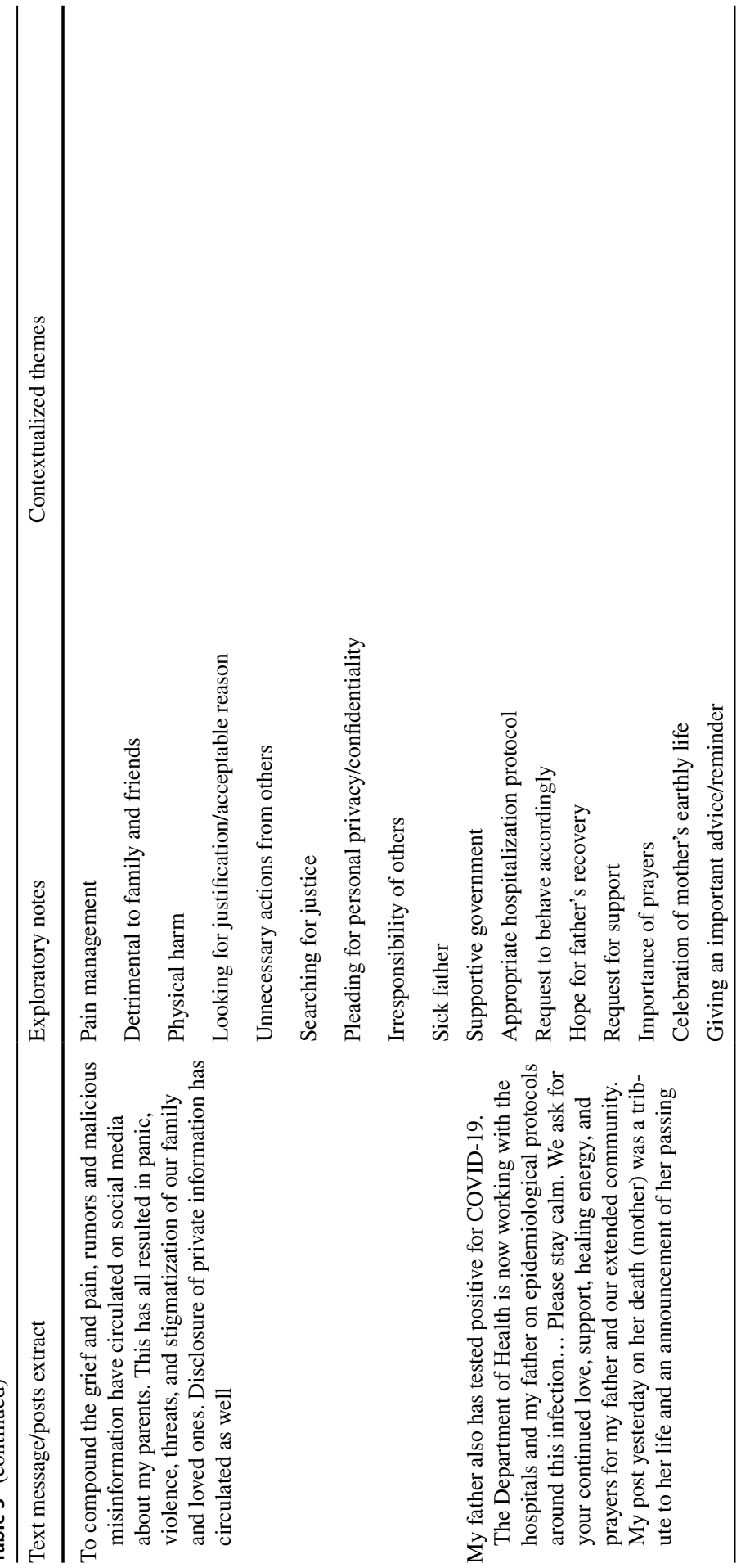




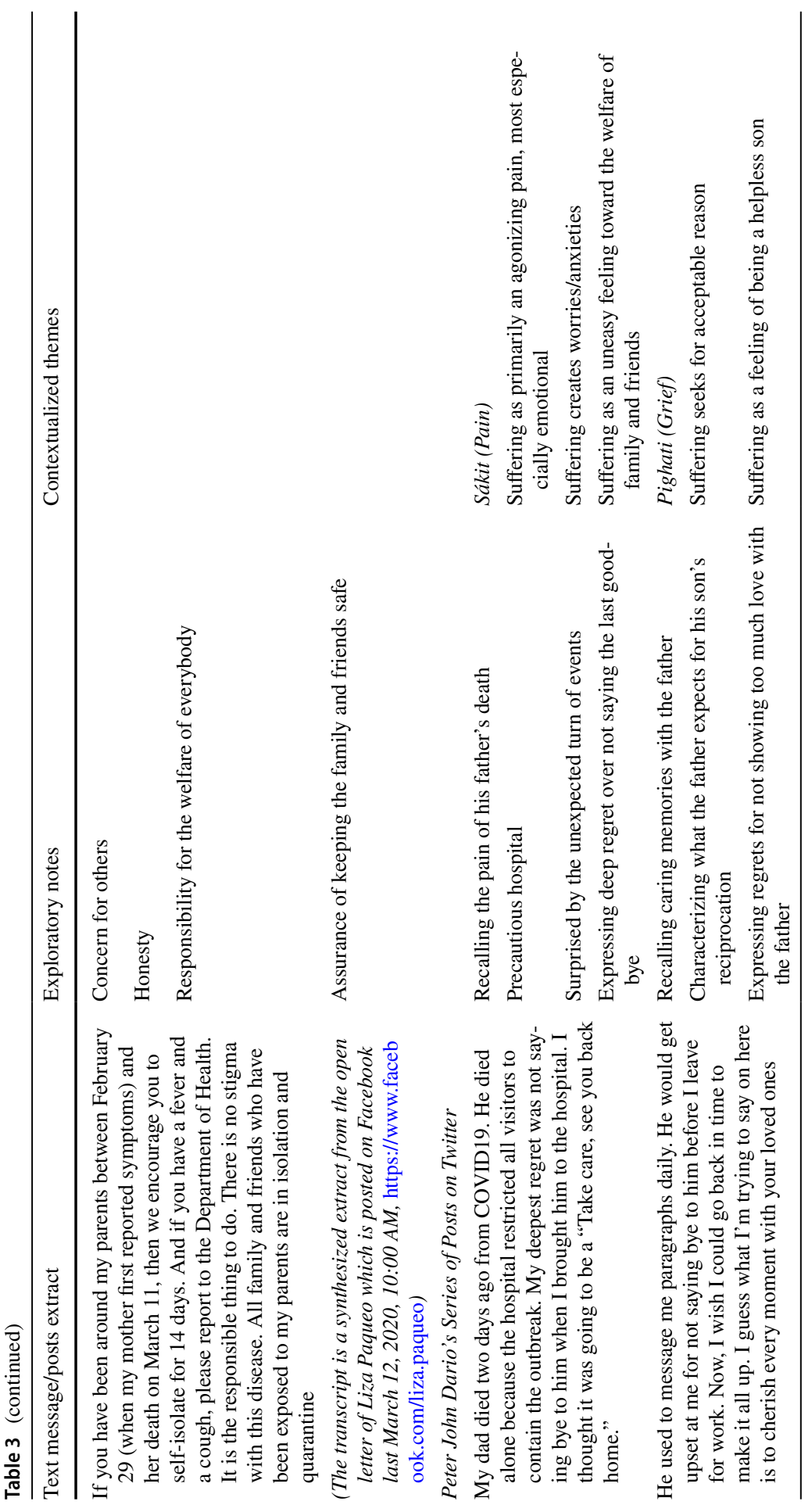




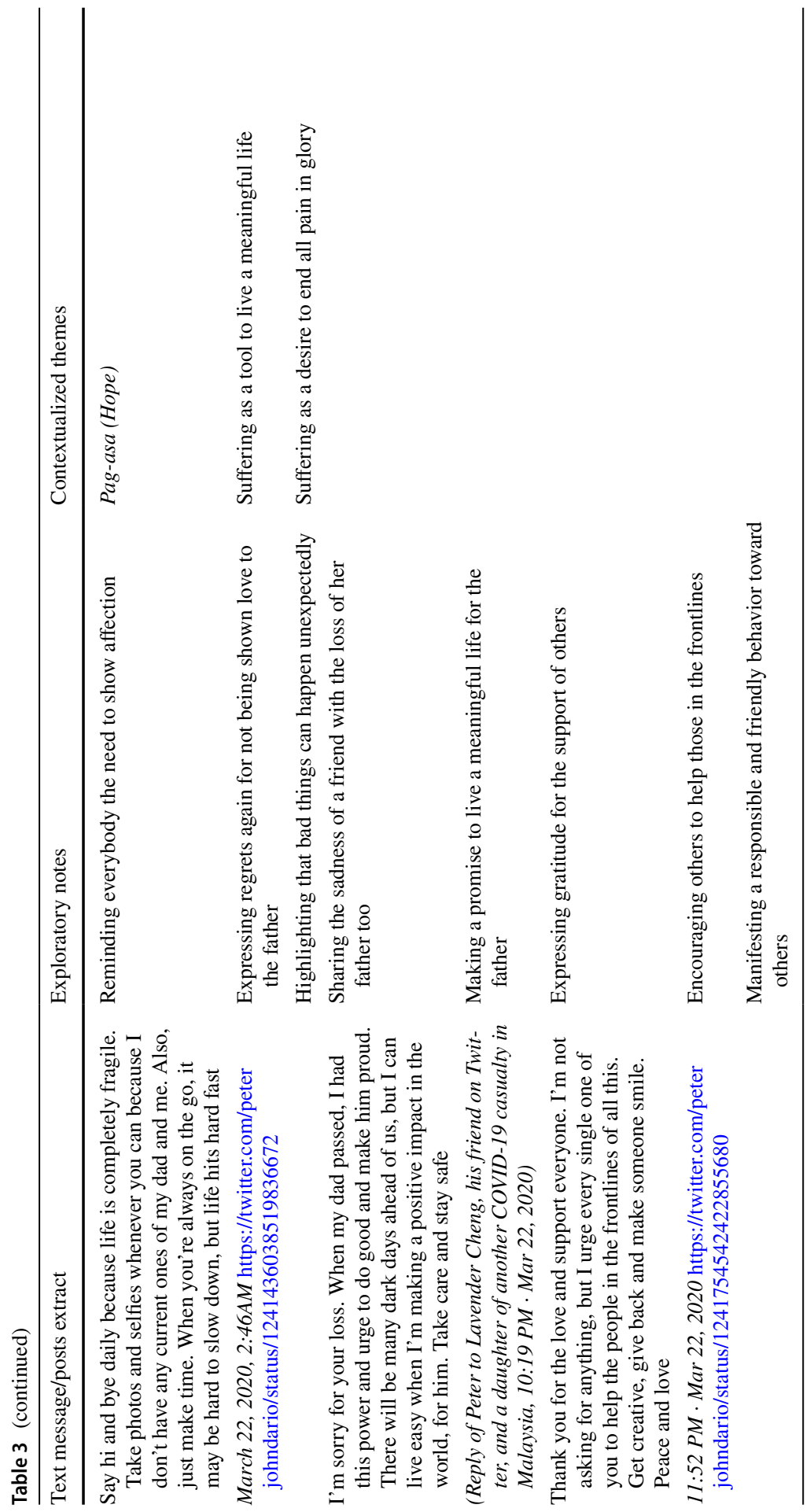


Liza and Peter John, on the other hand, felt so much emotional pain during the death of their parents as well as the surrounding unfortunate situation. It is a very hard time for Liza since she cannot even arrange the funeral of her mother. Aside from that fact, her father is also fighting for his life and she cannot be there to give support and comfort in that crucial moment. It is the same with Peter John. He brought his father to the hospital not knowing that it would be their last chance to be together. He was not able to seize the opportunity to express how he loved him. In deep pain, they wrote:

A few hours ago, my beautiful mother, Nida, was cremated. She died alone without her loving family and friends around her. She was cremated, alone, without ceremony or tribute... My father also has tested positive for COVID19... My father is alone as well. My brothers and I are together here in the United States, but we are not allowed to visit my dad. We are not allowed to manage and advocate for him. It has been painful not just for my nuclear family but for all our extended relatives and friends.

My dad died two days ago from COVID19. He died alone because the hospital restricted all visitors to contain the outbreak. My deepest regret was not saying bye to him when I brought him to the hospital. I thought it was going to be a "Take care, see you back home."

Sákit in the Filipino vocabulary is translated as pain. The other term which is spelled the same, sakit (stress on the second syllable), means an illness or disease. The former is also associated with the notions of hirap (hardship/difficulty) while the latter to kirot or hapdi (recurrent ache). These notions of pain practically help us to categorize it into two types: physical and emotional. When one is in physical pain, it is because of the bodily discomfort being felt such as those caused by different diseases or accidents. In different circumstances, emotional pain is brought by the negative feelings experienced from the death of loved ones, heartaches, problems, and trials. Tan (2013) argues that culture plays an important role in the way Filipinos experience and express pain. They locate where the pain is by naming the part of the body where the pain is felt, such as, sakit ng ulo (headache), sakit ng tiyan (stomachache) or sakit ng puso/kalooban (heartache). They express pain through sounds or language as a way of coping, seek comfort, or feeling better. A typical Filipino can utter expressions like maawa ka, ang sakit-sakit na (have mercy, it is very painful) or aray...aray... dahan-dahan lang naman mahapdi (be gentle... it hurts badly) can make the aching person find comfort and feel less pain. This expression of physical or emotional pain by Filipinos is supported by Geri-Ann Galanti, a medical anthropologist and professor of nurses at the University of California. According to her, some Filipino nurses validate the claim of administering a lower dosage of medicine to their patients even if the physician orders to give them a higher one. The reason for this is that some patients seem to beg for mercy as manifested in their language expressions. Galanti (2000) sees this as an opportunity to demonstrate virtue. They can be so expressive at times like moaning a lot to show that they are in pain. On the contrary, they can also be stoic which means they can endure pain or hardship without showing their feelings or complaining and that reflects their resiliency and endurance. Meanwhile, Tan (2015) in another article, adds that pain and suffering 
for Filipinos are inextricably related to sadness and misery. We suffer pain when we lose someone or something. Pain becomes suffering, too, because it disables us by preventing us from doing what we want and need. It is a feeling of helplessness. To conclude, no matter how intense the pain Filipinos feel, whether physical or emotional, they never forget to call on God to beg for awa (mercy). For them, it is their total dependency on God's mercy that brings consolation and comfort.

In Mt. 8.22 Jesus said, "Follow Me, and let the dead bury their dead." He was responding to a request from one of His disciples who asked to be excused because he needs to bury first his father. Others would interpret this as simply putting your spiritual responsibilities to God before all other obligations. This reminds me of Liza's situation of being unable to bury her dead mother. Some religious services are suspended to prevent the spread of COVID-19. However, for some Christians, these services are not just social gatherings but constitute a critical means to what is considered the most important ultimate end of communion with God (VanderWeele, 2020). In-person viewing of the body of those who died from COVID-19 was prohibited. The unusual process of grief in the time of COVID-19 challenges the usual process of coping with loss (Corpuz, 2021). Just like the disciple who responded to the calling of Jesus and needs to fulfill first his responsibility, Liza needs to be socially responsible too, to cooperate in the quarantine procedure for the safety of everybody. Responsibility to others first before one's own family. The emotional pain of the disciple, as well as that of Liza, describes what suffering brings to the table. As the pandemic compels us to physically distance ourselves from one another, we are given a unique lens to explore that a God of love (1 John 4.8, 16) equally keeps himself distant from humanity in certain regards (Ochs, 2020).

For Pope John Paul II (JPII), the theological teaching on suffering tells us that it is characterized primarily as an agonizing pain. The Pontiff himself had experienced this pain throughout his life. At age three, his mother died and three years later his only sibling died also. He was an orphan at twenty. He did hard labor in a stone quarry when the Nazis came to Poland. Many of his friends were killed, some in concentration camps, others shot simply for the desire to become priests. He nearly died when he was run down by a German truck. At sixty, an assassin shot him and nearly died again. As an old man, he suffered from Parkinson's disease that affected much his mobility and ability to speak (Kaczor, 2007). JPII indeed knows what it is to suffer and be in agonizing pain. In Salvifici Doloris (SD) (On the Christian Meaning of Human Suffering), JPII reiterates that to understand the problem of suffering and pain, one should look at it as inseparable from human existence as it is presented in different forms or dimensions. In short, suffering seems to belong to humanity's transcendence: It is one of those points in which they in a certain sense are "destined" to go beyond themselves, and they are mysteriously called to this (SD 1984, sec. 2-3). To be in pain is always attached to a human's reality of existence and what makes this existence meaningful is how he/she can respond well to this unfortunate situation. After all, suffering for Christians is characterized as beneficial. It is beneficial because it can unleash love in the human person, that unselfish gift of one's "I" on behalf of other people, especially those who suffer (SD 1984, sec. 29). Especially on what is happening nowadays, many rich people in the Philippines are more charitable by giving financial assistance and in-kind because they 
witness the suffering of the poor and marginalized caused by the pandemic. It is beneficial because pain can prompt rehabilitation, a turning from evil to embrace stronger relationships with others and with God (SD 1984, sec. 12), and can even draw a person interiorly close to Christ which will result in a conversion (SD 1984, sec. 26). This is the first dimension of suffering, it is always characterized by pain, in various forms and degrees.

\section{Pighati (Grief): Suffering Seeks for Acceptable Reason and Longs for Compassion}

Grief is an expression of deep sorrow that is usually caused by the loss/death of someone who has established a bond or closer attachment. It is an emotional reaction that is felt when a loved one is taken away and the pain is oftentimes overwhelming and the person experiences difficult emotions (Yap et al., 2021). There is no doubt that Liza and Peter John were in this state after the loss of their respective parents who were very loving to them. In fact, after a week, Liza made another two FB posts narrating the memorable experiences with her and her grandchildren as well. There is also an uploaded picture of them when she was still a small child and being carried by her mother. In the March 19 post, she linked it to her blog site entitled Liza Vida: My Life in an Albanian-Filipino Home. On this site, she shared in deep sorrow:

My mother loved being a grandmother; she just hated being called one. It made her feel old. And Mom-as most of you know-was and will be eternally youthful. So, when I was pregnant with my first child, Sebastian, she asked if she could be called Bella... My children loved their Bella, and when she passed away from COVID-19 on March 11, 2020, they were heartbroken... It is with deep regret that I am now taking my electronic pen back in hand and writing down my thoughts, and mom can no longer read it. I dedicate the Bella Vida page on this site to her. To my mom, the beautiful Bella, you are eternal to me.

Grief in the Filipino culture is known as pighati. It is usually characterized by sobrang kalungkutan (extreme loneliness). This type of emotion, as experienced by Liza, can be categorized into two. First, she was grieving because of the death of her beloved mother. In addition to that, she was not able to pay tribute for the last time with her physical presence. Second, this loneliness brings to her a sort of confusion and seeks for an acceptable reason why that particular tragedy needs to be coupled with other unfortunate things - the act of disrespect of other people against her family. Her words implied this:

... please do respect our family during this extremely painful time. It is dangerous, counterproductive, libelous, and ignorant to spread false information that could result in harm to our family and friends. But it can also be dangerous to public health and welfare... This has all resulted in panic, violence, threats, and stigmatization of our family and loved ones. Disclosure of private information has circulated as well. 
Pighati or grief is generally associated with the concept of loneliness. Loneliness is a holistic distressing experience of the self in which the person perceives oneself as worthless, very unhappy, and painfully alone by sensing life as meaningless due to a perceived deprivation of somebody or something in life is a need to love, to be loved, to cherish and to be satisfied with (Tharayil, 2012). This is I think a very good definition for it encompasses all the aspects of the concept. Loneliness does not simply mean being alone but can be a feeling of being alone even when we are with someone dear to us. This is seen as a very subjective feeling of distress (Peplau \& Perlman, 1982; Rice, 1990; Shahan, 1982). In our current situation, it is important to manage well the mental and spiritual health of everyone to minimize psychological damage in citizens and families. Also, it is necessary to undertake or reinforce a culture of human dignity where fundamental values are preserved to maintain an organized and healthy society in all aspects (Dutra \& Rocha, 2021).

Filipinos express their pighati through kalungkutan (loneliness), pagkalito (confusion), and longs for malasakit (compassion). Kalungkutan is characterized by a drop-in voice pitch and volume and facial muscles relaxed. When Filipinos are asked to express a neutral emotion, they tend to sound sad and look sad $(\mathrm{Cu}$ et al., 2013). It varies according to durations and degrees depending on the level of attachment to the person who has gone or died. Naturally, when one loses a very dear relative it takes time to move on and the support of other family members and friends are needed to recover. Pagkalito is manifested in the inability to think and act properly as one normally does because of unclear data. A grieving Filipino usually seeks an acceptable reason why such bad things occur to at least comfort him/her. It is natural for him/her to ask others for explanations. One may even come to the point of questioning the goodness of God for such a tragic event. Here, the state of confusion is influenced, in one way or another, by the sad feelings that are very strong at that specific moment.

During my first year of seminary formation at age 16, my father visited me and broke the sad news of my mother's death. I was shocked and confused because I do not remember any sickness of my mother that will lead to her death. Because of that, I used to cry every night and doubted the kindness of God. I even asked Him, "Is this my reward for entering the seminary to become a priest someday, of serving you for a lifetime?" Well, after some time I realized that I did that because I was just confused and indeed grieving at that time. Lastly, a Filipino in grief usually longs for malasakit (compassion). Malasakit is a popular Filipino trait that comes from the combined terms mala- (as if; like) and sakit (pain; ailment). When one says you have malasakit for the other, it would mean the other's pain is felt like it is your pain, your ailment too. It is more like felt compassion for one's fellow which has either a passive or active quality. It is passive if the feeling is not translated into action while it is active if translated into action (Cordero, 2019). Filipinos show of malasakit in this time of crisis is manifested through the offering of prayers and sharing what they have to help those in need and most affected. In Liza's case, many Filipinos expressed their malasakit by posting encouraging words and prayers on her social media accounts. This is validated by almost 9000 comments, 28,000 shares, and 36,000 total emoticons on FB as of March 22, 2020. 
Mt 5.4 stresses the concept of grief, "Blessed are they that mourn for they shall be comforted." This second beatitude establishes our mental recognition of our poverty of spirit by adding an emotional response of sorrow known as grief. Facing the evil in our own lives and this world saddens us and touches our emotions with grief. In any case, when we honestly mourn God sees our sorrow and comforts us with the knowledge that it will not always be this way (TOW Project 2016). Grief is a means of participating in and growth in the self-giving love manifested in the life of our Lord (Turner \& Carroll, 2001). Again, Salvifici Doloris emphasizes this participation and being witnesses in the Paschal Mystery of Christ:

Those who share in Christ's sufferings have before their eyes the Paschal Mystery of the Cross and Resurrection, in which Christ descends, in a first phase, to the ultimate limits of human weakness and impotence: indeed, he dies nailed to the Cross. But, if at the same time in this weakness, there is accomplished his lifting up, confirmed by the power of the Resurrection, then this means that the weaknesses of all human sufferings are capable of being infused with the same power of God, manifested in Christ's Cross. In such a concept, to suffer means to become particularly susceptible, particularly open to the working of the salvific powers of God, offered to humanity in Christ. (SD 1984, sec. 23)

Through grief, our interior lives mature and draw us nearer to Jesus because we can understand and feel in one way or another His sufferings and sacrifices. The sacrificial love that Jesus offered for us is more than enough for us to imitate and surrender to Him our sufferings and trials. Ewing (2020) claims that Jesus transforms our suffering into love. Ultimately, grief can lead us to greater compassion and empathy for the suffering of others. We become more attuned to the burdens that others carry, and we, in turn, accompany them in an authentic and genuinely loving way. Suffering and loss do not define us; they teach us how to love in a deeper and more meaningful way. When Job was grieving because of the various trials that came to his life, his friends were there at least to express their support:

When Job's three friends, Eliphaz the Temanite, Bildad the Shuhite, and Zophar the Naamathite, heard about all the troubles that had come upon him, they set out from their homes and met together by agreement to go and sympathize with him and comfort him. When they saw him from a distance, they could hardly recognize him; they began to weep aloud, and they tore their robes and sprinkled dust on their heads. Then they sat on the ground with him for seven days and seven nights. No one said a word to him, because they saw how great his suffering was. (Job 2.11-13)

In our daily experience, we turn to our family and friends in times of grief and trials. All the more, God listens to our sentiments. Gray (2019) posits that rather than suppressing our grief, the Bible gives us ample space to voice it out. Even better, it assures us that God hears us. David, the second king in the UK of Israel, 
declares in Psalm, "but God has surely listened and has heard my prayer. Praise be to God, who has not rejected my prayer or withheld his love from me!" (Ps. 66.19-20) Telling God our grief is another way of "offering it up" everything to God. Saying "offer it up" means that our suffering has worth/value, purpose, and meaning. God does not waste anything and wants us to hand our suffering in union with the Cross so that we might be purified by trials and tribulations. We can also offer up our pain and struggles in reparation for our sins or for others who are suffering from something similar (Ewing, 2020). This is what grief is all about. It is essential and necessary for us to be prepared in handling the last dimension of suffering which is hope.

\section{Pag-asa (Hope): Suffering as a Desire to End All Pain in Glory}

The Department of Health is now working with the hospitals and my father (tested positive) on epidemiological protocols around this infection... Please stay calm. We ask for your continued love, support, healing energy, and prayers for my father and our extended community... We want to concentrate our energy and our prayers on our father's recovery... My post yesterday on her death (mother) was a tribute to her life and an announcement of her passing... There is no stigma with this disease. All family and friends who have been exposed to my parents are in isolation and quarantine.

... When my dad passed, I had this power and urge to do good and make him proud. There will be many dark days ahead of us, but I can live easy when I'm making a positive impact in the world, for him.

These final posts from Liza and Peter John manifest the last dimension of suffering-pag-asa (hope). Liza expresses pag-asa with a positive disposition on the following expectations: that despite her mother's death her father will recover; that after the quarantine she and all their family and relatives will be free from the disease; that the people who misjudged and spread malicious rumors against them will be enlightened; and lastly, that the love and support to her family through prayers will continue until the crisis finally end. Peter John also hopes that the death of his father will be an eye-opener for him to live an inspirational and meaningful life so that his father will be proud of him. He hopes too that others will support, in one way or another, all those in the frontlines who have the noble task of saving the victims of this deadly virus.

Pag-asa in the Filipino culture is very rich in description. Jacklyn Cleofas, a notable Filipino philosophy professor describes what is going on with a person who exhibits pag-asa. According to her, a person who hopes experiences like being pushed into the pit of darkness but finds ways to get out and see the light (Cleofas, 2015). Ferriols (2001), on the other hand, points out that another characteristic of a person who hopes is patience. Patience is manifested through trust in one's relationship with others. Pag-asa is an important index of wellbeing, particularly among individuals who experience distress or who live in dire circumstances (Bernardo \& Estrellado, 2014). Lastly, pag-asa for Filipinos is always associated with the concept of redemption. Whether our suffering happens beyond our control or not, suffering 
can have a redemptive meaning. It can draw good out of evil, convert losses into gains, and, rightly offered, can gain us eternal life (San Luis, 2020). Thus, the concept of redemptive suffering is emphasized with hope.

But what is redemptive suffering in the first place? The word "redeem" means to rescue, set free, or pay the penalty that is committed by the other. Redemptive suffering is the personal sacrifice that Christians unite with Christ's sacrifice that He made of Himself to God. There is a precious value brought by the sacrifices of the members of the Church, that is, for the atonement of sin and to call down God's blessings on humanity (Eli, 2020). One controversial Filipino traditional practice during Lent epitomizes and exaggerates this concept. It is the practice of flagellation and live crucifixion that usually happens in the province of Pampanga. The participants scourge their backs, carry the cross, and even undergo the life-threatening crucifixion. Though this practice was already banned by the Church they cannot stop doing it since it is already part of the tradition and a form of panata (sacred promise) that they need to fulfill to atone their sins and for their other intentions such as healing and request for blessings. Pag-asa in this sense is brighter for them because they find meaning as they suffer.

The Catechism of the Catholic Church teaches that "By his passion and death on the cross Christ has given a new meaning to suffering: It can henceforth configure us to him and unite us with his redemptive Passion" (sec. 1505). This implies that our suffering becomes a participation in the sacrifices and suffering of Jesus. Thus, concerning hope, suffering gives us hope that someday, just like Christ, we will also resurrect. In this time of the pandemic, some Christians claim that COVID-19 is proof that the plagues of the Book of Revelation are occurring now and Jesus' return is imminent. For them, Revelation has indeed predicted the COVID-19 pandemic (Dein, 2021). The current crisis reminds us to be careful in speculating on the origins or purposes of such crises. Reading the bible can bear witness to the divine promise of hope in the healing justice of God, and calls human persons and human communities to participate in that justice through responsible action (Brett \& Goroncy, 2020). The Old Testament books of Genesis, Exodus, Ruth, Samuel-Kings, and Chronicles include several stories about epidemic and famine that may resource us as we wonder how to think about the COVID-19 pandemic, about how God might be involved in it, about the past and the future, and about what our response to it might be (Goldingay \& Goldingay, 2020). The Catechism adds that the virtue of hope keeps man from discouragement; sustains him during times of abandonment, and opens up his heart in expectation of eternal beatitude (sec. 1818). Meaning, there is that sense of assurance that everything will not come to waste because for as long as we keep ourselves accessible to the grace of God then we will be victorious.

Salvifici Doloris points out a vivid expression of the concept of hope using the story of Job. The Hebrew Bible introduces Job as the grandson of Esau and a ruler of Edom. We have known that Job is the story of a just man, who is tried by innumerable sufferings-loses his possessions, his sons and daughters, and finally, he is afflicted by severe sickness. He, however, challenges the principle that suffering is brought by one's sinfulness primarily because he is innocent. The punishment given to Job creates the possibility of rebuilding goodness in him 
who suffers. That is the sense of hope which has the purpose of strengthening the goodness both in man himself and in his relationships with others and especially with God (sec. 12). And of course, Job's story portrays the hope that all his trials will come to an end that had happened. God gave him more than what he wanted:

After Job had prayed for his friends, the LORD restored his prosperity and doubled his [previous] possessions. All his brothers, sisters, and former acquaintances came to his house and dined with him in his house... So the LORD blessed the latter part of Job's life more than the earlier. He owned 14,000 sheep, 6,000 camels, 1,000 yoke of oxen, and 1,000 female donkeys. He also had seven sons and three daughters. Job lived 140 years after this and saw his children and their children to the fourth generation. Then Job died, old and full of days. (Job 42. 10-17)

Job's story is all about suffering and yet filled with hope. It teaches us that no matter what level or status in life we are in, whether we are sinful or innocent, we are not exempted from suffering. However, it is not the end of the story. We can always hope to succeed by patiently holding on to Him. The only question is whether we will allow God to work in our whole being as Job did.

\section{Limitations}

The limitations of this study include the small cohort size. It is a very small sample indeed and therefore the findings are not generalizable. There may have been other significant points as emphasized in John Paul II's apostolic letter Salvifici Doloris. There are other reflections in the letter which were not fully exhausted in this paper like the beauty and happiness in suffering, the necessity of heartfelt compassion, the imperative of faith, and many others. Also, it may be difficult to determine other factors which may have influenced the respondents as they narrated their personal experiences of suffering. They may have, for example, been so emotional with their respective unfortunate situation that this influenced what they shared in their narratives.

\section{Concluding Reflections}

The text message of Dr. Greg and social media posts of Liza and Peter John are Filipino narratives of suffering as expressed in various subjects and predicaments. Dr. Greg worked on the front lines of saving the lives of COVID-19 patients in the hospital. He was unfortunately infected with the disease, suffered agonizing pain, and died in the line of duty-living up to his sworn Hippocratic Oath. Liza is a loving daughter who experienced profound grief. She bore the loss of her dear mother without having the chance of paying last respects to her and at the same time was even prohibited to visit her sick father. Who could forget Peter John, the father's junior? After bringing his father to the hospital, he did not know that it would be their last 
moment together. Full of hope, Peter John promised his father that he will make him proud by making a positive impact in this world. He also requested prayers and support for all those in the frontlines of this pandemic-indeed hoping that it will end soon.

As the concept of suffering presents three dimensions of sákit, pighati, and pag$a s a$, I have realized that to better understand this phenomenon is to know certain basic realities which will be my reflections within this paper. The first reality points out suffering as a permanent part of human life. Adam and Eve, the first man and woman in the Judeo-Christian and Islamic traditions, were subjected to the curse of God after their disobedience. Humanity would now suffer in the work they were assigned to do, while corruption, sickness, and death were introduced to God's good creation. The effect of COVID-19 is remarkably progressing and causing more people to suffer worldwide. Rich or poor, man or woman, young or old, Filipinos or Americans, no matter what race, gender, or social status one belongs to, anybody can be infected with the virus. Since nobody is immune and exempted from suffering, the question now does not lie in its universality but in the particular responses of every person who confronts it. What should be my proper disposition amid my suffering?

The second reality is found in the meaning brought by the cross of Christ. Since suffering is a part of life, attached to it is the cross that we must bear. The cross is not useless because it conveys a meaningful reality-someone is sharing in our suffering. Let us not forget that suffering is traditionally represented by the image of the cross. The cross is a reminder that to suffer is to be human and one cannot experience painful loss without the accompaniment of suffering. It is on the cross where Christ suffered that we can better understand suffering. We have Christ as our co-sufferer whenever we suffer. As we share in Christ's sufferings on the cross, we also share Christ's comfort in our sufferings. Our idea that God as being a cosufferer gives meaning to our suffering. The suffering of Christ provided us not only the grace of forgiveness of our sins but also lightens the burden of our suffering. Therefore, this makes the cross not only a symbol of suffering but of triumph over sin and death. It gives us a wonderful message that out of anything bad, painful, or tragic, something good can happen. The next practical question is to determine its aftermath. How does my suffering affect/change me?

The last reality has something to do with the concept of transcendence after having undergone suffering. Some people claim that after having experienced a lot of suffering there is nothing left to them. Since they have lost everything like the death of loved ones, loss of properties, or being heartbroken, then there is no more reason to live. On the contrary, some argue that suffering made them stronger and better persons. It pushes them to their limits to achieve their full potential. During this pandemic, those people experiencing fear, suffering, or illness often experience a "spiritual renewal" in which the development of spirituality will create a mature attitude based on truth and freedom (Kowalczyk et al., 2020). This is where the reality of "pag-asa" (hope) comes in. It is finding the light at the end of the tunnel. There is still a reason to believe that all shall be well. I remember my favorite biblical passage, "That is why, for Christ's sake, I delight in weaknesses, in insults, in hardships, in persecutions, in difficulties. For when I am weak, then I am strong" (2 Cor. 
12.10). St. Paul, one of the leaders of the first generation of Christians, wanted the Corinthians to know about his weaknesses by letting them look into his life so that they would also realize the powerfullness of Christ. This weakness of St. Paul is necessary because it leaves space in his being for the strength of Christ which completes him and pushes him to be at his best. I firmly believe that suffering creates in us the motivation to bring out what is best in us. This motivation is the starting point of the journey toward "pag-asa". When my mother died unexpectedly when I was in college, I became so sickly for many years. Some years after, my father died next and I thought it was the end of everything for me, since these trials kept on coming. However, God pushed me hard to overcome these agonies and made me a stronger person. I firmly believe that even if I face more trials in the future, I can handle them since I was already tested by fire again and I realize now what I am capable of achieving. I have been through this before and as the Lord said to St. Paul, "My grace is sufficient for you, for my power is made perfect in weakness" (2 Cor. 12.9). I believe the Lord tells me the same words. My suffering enabled me to attain transcendence which leads me to a brighter "pag-asa". I developed a deeper relationship with God and had established a more harmonious relationship with others. This experience does not require an affiliation to any religion but is characterized as "deeply spiritual." Suffering enables us to come up toward a transcendent reality. For Christians, this reality is girded toward a good God who created us as by nature good. The experience of suffering gives us the chance to go back and rediscover this goodness. We are capable of transcending the painful effects of suffering because God created us as such and God never desires that we will be separated from that goodness.

Acknowledgements The author acknowledges all the participants for their very thoughtful sharing of personal sentiments regarding the experience. This research is also dedicated to all who are experiencing suffering brought by the COVID-19 pandemic.

Funding This study received no funding outside of the author's expense.

\section{Declarations}

Conflict of interest The author declares that there is no conflict of interest.

Human and Animal Rights This article does not contain any studies with animals performed by the author.

Informed Consent Informed consent was obtained from all individual participants included in the study. Specific permission has been granted to the authors to publish details of personal Facebook pages.

\section{References}

Bernardo, A., \& Estrellado, A. (2014). Measuring hope in the Philippines: Validating the short version of the locus-of-hope Scale in Filipino. Social Indicators Research, 119, 1649-1661. https://doi.org/10. 1007/s11205-013-0573-7. 
Boyatzis, R. (1998). Transforming qualitative information: Thematic analysis and code development. Sage.

Braun, V., \& Clarke, V. (2006). Using thematic analysis in psychology. Qualitative Research in Psychology, 3, 77-101.

Brett, M., \& Goroncy, J. (2020). Creation, god, and the coronavirus. Theology, 123, 346-352. https://doi. org/10.1177/0040571X20944579.

Caulfield, J. (2019). How to do thematic analysis. Scribbr. Retrieved September 6, from https://www. scribbr.com/methodology/thematic-analysis/.

Cleofas, J. (2015). Konsepto at pag-asa ayon kay Ferriols. Perspectives in the Arts \& Humanities Asia, 5 , 21-40.

Cordero, D., Jr. (2018). Understanding the broader horizon of sexual encounter: A case study on sexual engagement among Filipino teens. Asia-Pacific Social Science Review, 18, 46-61.

Cordero, D., Jr. (2019). Free and creative communal compassion: Reconstructing a contextualized Filipino ethics of sexuality. Philosophia-International Journal of Philosophy, 20, 19-38.

Corpuz, J. (2021). Beyond death and afterlife: The complicated process of grief in the time of COVID19. Journal of Public Health. https://doi.org/10.1093/pubmed/fdaa247.

$\mathrm{Cu}$, J., Solomon, K., Suarez, M., \& Sta Maria, M. (2013). A multimodal emotion corpus for Filipino and its uses. Journal on Multimodal User Interfaces, 7, 135-142. https://doi.org/10.1007/ s12193-012-0114-8.

Davey, M. (2020). What is a pandemic and does it change the approach to coronavirus? The Guardian, Retrieved March 14, from https://www.theguardian.com/world/2020/mar/14/what-is-a-pandemiccoronavirus-covid-19.

Dein, S. (2021). Covid-19 and the apocalypse: religious and secular perspectives. Journal of Religion and Health, 60, 5-15. https://doi.org/10.1007/s10943-020-01100-w.

Dulles, S. J., \& A. (2003). The splendor of truth: The theological vision of Pope John Paul II. . Crossroad Publishing Company.

Dutra, C., \& Rocha, H. (2021). Religious support as a contribution to face the effects of social isolation in mental health during the pandemic of COVID-19. Journal of Religion and Health, 60, 99-111. https://doi.org/10.1007/s10943-020-01140-2.

Eli, B. (2020). Redemptive suffering. Church Militant. https://www.churchmilitant.com/catholicism/artic le/catholicism_redemptive-suffering.

Ewing, J. (2020). Here is a Catholic guide to understanding grief. The mystical humanity of christ, Retrieved March 21, from https://www.coraevans.com/blog/article/here-is-a-catholic-guide-to-under standing-grief.

Ferriols, R. (2001). Pilosopiya ng relihiyon. (2nd ed.). Quezon City: Ateneo de Manila University.

Galanti, G. (2000). Filipino attitudes toward pain medication: A lesson in cross-cultural aare. Western Journal of Medicine, 173, 278-279. https://doi.org/10.1136/ewjm.173.4.278.

Goldingay, J., \& Goldingay, K. (2020). Thinking with the old testament about the pandemic. Theology. https://doi.org/10.1177/0040571X20920527.

Gray, B. (2019). A theology of grief \& death. 1517 Christ for you. Retrieved October 3, from https:// www.1517.org/articles/a-theology-of-grief-death.

Kaczor, C. (2007). A Pope's answer to the problem of pain. Catholic Answers. Retrieved January 1, from https://www.catholic.com/magazine/print-edition/a-popes-answer-to-the-problem-of-pain.

Kowalczyk, O., Roszkowski, K., Montane, X., Pawliszak, W., Tylkowski, B., \& Bajek, A. (2020). Religion and faith perception in a pandemic of COVID-19. Journal of Religion and Health, 59, 26712677. https://doi.org/10.1007/s10943-020-01088-3.

Lincoln, Y., \& Guba, E. G. (1985). Naturalistic inquiry. . Sage.

Nowell, L., Norris, J., White, D., \& Moules, N. (2017). Thematic analysis: Striving to meet the trustworthiness criteria. International Journal of Qualitative Methods, 16, 1-13. https://doi.org/10.1177/ 1609406917733847.

Ochs, C. (2020). God's self-distancing: What a global pandemic might teach us about God. Theology. https://doi.org/10.1177/0040571X20944580.

Peplau, L., \& Perlman, D. (1982). Loneliness: A sourcebook of current theory, research and therapy. . Wiley.

Rice, K. (1990). Attachment in adolescence: A narrative and meta-analytic review. Journal of Youth and Adolescence, 19, 511-538. https://doi.org/10.1007/BF01537478.

San Luis, B., \& SVD. (2020). Redemptive suffering. Manila Bulletin, Retrieved April 14, from https:// news.mb.com.ph/2019/04/14/redemptive-suffering/. 
Shahan, L. (1982). Living alone and liking it. . Stratford Press.

Tan, M. (2013). Filipino pain. Inquirer.net. Retrieved July 16, from https://opinion.inquirer.net/56715/ filipino-pain.

Tan, M. (2015). Culture and pain. Inquirer.net. Retrieved March 27, from https://opinion.inquirer.net/ $83647 /$ culture-and-pain.

Tharayil, D. (2012). Developing the university of the Philippines loneliness assessment scale: A crosscultural measurement. Social Indicators Research, 106, 307-321.

Thomas, D., \& Nair, A. (2020). Canada identifies first case of coronavirus. Reuters. Retrieved January 26, from https://www.reuters.com/article/us-china-health-canada-idUSKBN1ZO0T9.

Turner, C., \& Carroll, P. (2001). Grief management and the Catholic Church, Unity Publishing. Retrieved November 12, from http://www.unitypublishing.com/Newsletter/CarmellaDeath.html.

VanderWeele, T. (2020). Love of neighbor during a pandemic: Navigating the competing goods of religious gatherings and physical health. Journal of Religion and Health, 59, 2196-2202. https://doi. org/10.1007/s10943-020-01031-6.

World Health Organization. (2020). Q\&A on coronaviruses (COVID-19). WHO Int. Retrieved March 9, from https://www.who.int/news-room/q-a-detail/q-a-coronaviruses.

Yap, J., Garcia, L., Alfaro, R., \& Sarmiento, P. (2021). Anticipatory grieving and loss during the COVID19 pandemic. Journal of Public Health. https://doi.org/10.1093/pubmed/fdaa258.

Publisher's Note Springer Nature remains neutral with regard to jurisdictional claims in published maps and institutional affiliations. 